DOI: https://doi.org/10.36477/tourismhospcee-2-1

UDC 338.48

\author{
Halina Powęska \\ DSc, Associate Professor, \\ Development Policy and Marketing Institute of Economics and Finance, \\ Warsaw University of Life Sciences \\ ORCID: https://orcid.org/0000-0002-6122-9517
}

\title{
DOBRA KULTURY JAKO OBIEKTY AKTYWIZACJI TURYSTYCZNEJ W MIEJSCOWOŚCIACH O DOMINUJĄCEJ ROLI WALORÓW WYPOCZYNKOWYCH
}

\section{HERITAGE ASSETS AS THE OBJECTS FOR ACTIVIZATION OF TOURISM IN LOCALITIES WITH DOMINATING RECREATIONAL ACTIVITY}

\begin{abstract}
Wstęp. Turystyka pozytywnie wpływa na rozwój społeczno-gospodarczy miejscowości i regionu (Suhel, Bashir, 2018), co w skali lokalnej uwidacznia się przede wszystkim w szeroko rozumianym dziale usług turystycznych i paraturystycznych (Rukuižienè 2014). Rozwój funkcji turystycznej, jako funkcji społeczno-gospodarczej ma szczególnie istotne znaczenie w tych jednostkach samorządu terytorialnego stopnia podstawowego (gminy, communs), w których zlokalizowane walory turystyczne dają podstawę do intensyfikacji ruchu turystycznego, i w ten sposób zarówno zasoby przyrodnicze jak i dobra kultury stanowią bardzo ważny czynnik i atrybut rozwoju lokalnego (Korkuna, Korkuna, Kulyk, 2020; Eversole 2006; Cernea 2001). Wzajemnie uzupełnienie oddziaływania walorów antropogenicznych i przyrodniczych stanowi o atrakcyjności turystycznej regionów (Koteski C., Jakovlev Z., Bardarova S., 2013). W regionach o dominacji walorów przyrodniczych istnienie walorów antropogenicznych jest ważnym elementem podnoszącym atrakcyjność turystyczną, co ma wpływ na poziom zadowolenia turystów z pobytu w tych miejscowościach (McKercher, P., Ho, P.S.Y, Cros du H., 2005).

Zagadnienie oddziaływania dóbr kultury na ruch turystyczny zostało dość dobrze zbadane w odniesieniu do tych gmin, w których można mówić o dominacji walorów antropogenicznych nad przyrodniczymi (Herrero-Prieto L.C, Gomez-Vega M., 2017; Towse 2010; Bedate A., Herrero L.C., Sanz J.A., 2004). Natomiast bez odpowiedzi pozostaje pytanie $\mathrm{w}$ jakim zakresie walory antropogeniczne wpływaja na ruch turystyczny $w$ gminach i regionach, w których zaznacza się wyraźna dominacja walorów przyrodniczych nad antropogenicznymi? Czy pomimo głównych atrakcji związanych z elementami przyrodniczymi dobra kultury również wpływają stymulująco na ruch turystyczny powodując jego intensyfikację? Biorąc powyższe pod uwagę autorka podjęła badania mające na celu określenie w jakim zakresie dobra kultury wpływają na ruch turystyczny
\end{abstract}

w tych jednostkach samorządu terytorialnego, w których wyraźnie dominują walory przyrodnicze, jednakże walory antropogeniczne, mające tylko uzupełniające znaczenie, są także interesujące. Ponadto rodzi się pewnego rodzaju pytanie o charakterze praktycznym: czy dbałość o dobra kultury w regionach przyrodniczych i wypoczynkowych wpływa tylko na poprawę estetyki krajobrazu, czy zadbane, a czasem wykreowane przez władze lokalne, dobra kultury także przyczyniają się w obszarach o dominacji walorów przyrodniczych i wypoczynkowych do zwiększania ruchu turystycznego.

Założenia metodyczne. Proponowana praca utrzymana jest $\mathrm{z}$ jednej strony w szeroko rozumianej dziedzinie określanej jako nauki o turystyce, przy dominacji podejścia ekonomicznego (Bertacchini E., Nogare C.D., 2021), z uwzględnieniem aspektów przestrzennych (Hall C.M., Page S.J., 2014) i socjologicznych (Mensah 2016), a z drugiej strony sięga do dorobku ekonomiki kultury, jako dziedziny ekonomii związanej z ekonomicznymi aspektami dóbr kultury, a także $z$ dystrybucją i konsumpcją dóbr natury (Ilczuk). Przy wykorzystaniu dorobku wielu dziedzin nauki możliwe jest uchwycenie właściwego kontekstu analizy zjawiska, pozwalające na właściwą ocenę znaczenia dóbr kultury w rozwoju lokalnym i regionalnym (Murzyn-Kupisz).

Bazując na obserwacjach własnych miejscowości turystycznych, w których głównym magnesem przyciągającym ruch turystyczny są walory wypoczynkowe (np. położenie nadmorskie, plaże nadmorskie, sprzyjający klimat), autorka postawiła pytanie badawcze czy i w jakim zakresie w wypoczynkowych miejscowościach turystycznych, także dobra kultury oddziałują stymulująco na ruch turystyczny? Czy dystans/odległość między miejscem zamieszkania a odwiedzanym regionem wpływa na poziom zainteresowania obiektami kultury? Autorka wstępnie postawiła tezę, że w regionach turystycznych o dominującej roli przyrodniczych oraz wypoczynkowych walorów turystycznych dobra kultury nie 
pełnią kluczowej roli, jednak przyczyniają się do zwiększenia ruchu turystycznego.

Celem udowodnienia tej tezy autorka przeprowadziła badania terenowe $\mathrm{w}$ dwóch jednostkach samorządu terytorialnego spełniających następujące kryteria:

- istnieje w tych gminach ruch turystyczny,

- wspólną cechą jest dominacja walorów wypoczynkowych, przy czym występują także interesujące walory antropogeniczne,

- władze tych jednostek przykładają dużą wagę do kwestii zachowania dóbr kultury,

- istnieje dobry klimat do rozwoju turystyki, a władze tych jednostek samorządu terytorialnego prowadzą działania mające na celu rozwój turystyki.

Zgodnie z założeniami do badania wybrano jednostki samorządu terytorialnego na poziomie lokalnym, w których w strukturze walorów turystycznych wyraźnie dominują walory wypoczynkowe nad antropogenicznymi, natomiast te drugie są również interesujące i mogą być istotnym elementem przyciągającym turystów. Badanie przeprowadzono w dwóch miejscowościach nadmorskich: w gminie Thanet w hrabstwie Kent w Wielkiej Brytanii oraz w mieście Hel w województwie pomorskim w Polsce. Badanie przeprowadzono metodą sondażu diagnostycznego, za pomocą techniki wywiadu. W każdej miejscowości badanie przeprowadzono w okresie wakacyjnym, w miesiącu sierpniu, który jest intensywnym okresem wypoczynku w tych miejscowościach. W czasie prowadzenia badań, zarówno $\mathrm{w}$ Wielkiej Brytanii jak i w Polsce, istotnym wydarzeniem odbywającym się corocznie od kilku lat były imprezy historyczno-kulturowo-plenerowe, będące dodatkową atrakcją turystyczną we wskazanych jednostkach administracyjnych.

W czasie wywiadu respondenci byli pytani o sposób spędzania czasu w trakcie realizacji swojego pobytu turystycznego. Zasadnicze pytanie dotyczyło struktury czasu przeznaczonego na różne formy wypoczynku. Respondenci mieli do wyboru następujące kategorie aktywności: na plaży, w obiektach kultury, w obiektach gastronomicznych, na spacerze, jeżdżąc rowerem. Respondenci mogli wskazać także kategorię inne i samodzielnie określić sposoby i formy spędzania czasu. Dla każdej z tych kategorii spędzania wolnego czasu respondenci określali liczbę godzin (minut), którą poświęcili w ciągu dnia tej formie aktywności. Turyści wskazywali również miejsce oraz region swojego zamieszkania, określali także grupę osób towarzyszących, z którymi przyjechali oraz przebywali w danej miejscowości. Dalej grupa osób towarzyszących jest określona jako grupa wypoczynku. Respondenci mieli do wyboru następujące grupy wypoczynku: przyjazd rodzinny, małżeństwo/związek partnerski, grupa przyjaciół, zorganizowana grupa turystyczna, wyjazd indywidualny. W przypadku rodziny, grupy przyjaciół i zorganizowanej grupy turystycznej zapytano ile osób wchodziło w skład grupy wypoczynku, zaś w przypadku małżeństwa/związku partnerskiego i wyjazdu indywidualnego przyjęto odpowiednio dwie i jedną osobę.

W ten sposób przeprowadzając w Thanet 37 wywiadów badaniem objęto 242 turystów, a w Helu wykonując 63 ankiety uzyskano informacje dotyczące 411 turystów. W obu jednostkach administracyjnych bardzo duży udział wśród turystów objętych badaniem mieli członkowie zorganizowanych grup turystycznych oraz rodziny z dziećmi (Tabela 1). Istotną rolę odgrywały także grupy przyjaciół.

$\mathrm{Na}$ podstawie zebranego materiału badawczego przeprowadzono: (1) analizę zależności między długością pobytu $\mathrm{w}$ miejscowości turystycznej a zasięgiem przestrzennym miejsca zamieszkania i pochodzenia turystów, a następnie (2) scharakteryzowano strukturę czasu wypoczynku dominujących grup turystów i na tej podstawie określono znaczenie dóbr kultury w stymulowaniu ruchu turystycznego w poszczególnych miejscowościach.

Charakterystyka obszarów badawczych. Wybrane do badania jednostki samorządu terytorialnego są jednostkami szczebla podstawowego w trójstopniowym podziale terytorialnym. Charakteryzując obszary badawcze zwrócono szczególną uwagę na czynniki rozwoju, wynikające z położenia jednostek oraz zaistniałe w procesie rozwoju historycznego najważniejsze funkcje społeczno-gospodarcze,

Struktura grupy badawczej

Tabela 1

\begin{tabular}{|l|c|c|c|c|}
\hline \multirow{2}{*}{ Grupa wypoczynku } & \multicolumn{2}{|c|}{ Thanet } & \multicolumn{2}{c|}{ Hel } \\
\cline { 2 - 5 } & $\begin{array}{c}\text { liczba } \\
\text { wywiadów }\end{array}$ & $\begin{array}{c}\text { liczba osób objętych } \\
\text { wywiadem }\end{array}$ & $\begin{array}{c}\text { liczba } \\
\text { wywiadów }\end{array}$ & $\begin{array}{c}\text { liczba osób objętych } \\
\text { wywiadem }\end{array}$ \\
\hline Rodzina & 17 & 75 & 32 & 118 \\
\hline małżeństwo/konkubinat & 8 & 16 & 8 & 16 \\
\hline grupa przyjaciół & 9 & 43 & 15 & 75 \\
\hline zorganizowana grupa turystyczna & 2 & 107 & 5 & 199 \\
\hline wyjazd 1-osobowy & 1 & 1 & 63 & 3 \\
\hline Razem & 37 & 242 & & 411 \\
\hline
\end{tabular}

Źródło: opracowanie własne 
mające wpływ na zakres i charakter walorów antropogenicznych.

Gmina Thanet położona jest w południowowschodniej Anglii (Wielka Brytania), w hrabstwie Kent. Czynnikiem, który zarówno w przeszłości jak i współcześnie odegrał bardzo ważną rolę w rozwoju tego obszaru jest położenie nadmorskie, łagodny klimat oraz szeroka plaża, która stanowi obecnie o atrakcyjności turystycznej gminy, natomiast historycznie umożliwiała łatwy dostęp lądu przybywającym od strony morza żeglarzom. Historia Thanet sięga czasów rzymskich, kiedy to obszar ten wyspą. W I stuleciu p.n.e. na wyspie Thanet wylądowały okręty rzymskie, których zadaniem miała być ochrona przybywających do Brytanii statków Juliusza Cezara. Ukształtowanie terenu stanowily naturalny port umożliwiający szybkie cumowanie okrętów Cezara i zejście na ląd legionistów rzymskich. Dla ich potrzeb zbudowano także fort. Po upadku cesarstwa rzymskiego i wycofaniu się rzymian zaczęli przybywać na wyspę przedstawiciele innych nacji. W IX wieku w okresach zimowych odwiedzali ten obszar wikingowie, a w następnych stuleciach stopniowo osiedlali się na terenie Thanet Anglosasi. W VI wieku założyli oni w Minster-in-Thanet klasztor i zaczęli dominować w tym terenie. Położenie nadmorskie sprzyjało rozwojowi rybołówstwa, a na dogodnych glebach w ciepłym nadmorskim klimacie rozwijało się rolnictwo. Położenie nadmorskie w sąsiedztwie Kanału La Manche powodowało, że następnych stuleciach obszar ten miał ważne znaczenie strategiczne. Thanet odegrało istotną rolę podczas wojen napoleońskich, a w czasie I i II wojny światowej pola uprawne tego terenu stanowily dogodne miejsca dla lotnictwa. W czasie I wojny światowej były to lotniska awaryjne, zaś podczas II wojny światowej lotnisko RAF-u w Manston (obecnie nazywa się Kent International Airport) odegrało ważną rolę w Bitwie o Anglię. Położenie nadmorskie oraz warunki klimatyczne przyczyniły się do rozwoju turystyki w tym terenie. Za sprawą tych czynników od XIX wieku miejscowości Thanet stawały się nadmorskimi kurortami, w szczególności często odwiedzanymi przez mieszkańców Londynu, a w połowie XIX wieku doprowadzono tam kolej. W kolejnych dziesięcioleciach funkcja turystyczna zaczęła odgrywać dominującą rolę, a współcześnie region ten stał się bardzo atrakcyjny nie tylko dla mieszkańców Londynu, ale także dla turystów z innych obszarów Wielkiej Brytanii i zza granicy. Władze lokalne przywiązują dużą wagę do kwestii obsługi ruchu turystycznego, wzbogacają ofertę turystyczną dbając o lokalne walory turystyczne i rozbudowując ofertę kulturalną. Na szczególną uwagę zasługuje znajdująca się w Margate galeria sztuki współczesnej Turner Contemporary, zaplanowana jako przestrzeń sztuki współczesnej i katalizator rewitalizacji miasta. Nazwa galerii przywołuje pamięć o znanym malarzu pejzażowym
J.M.W. Turnerze (1775-1851), który uczęszczał do szkoły w Margate i odwiedzał Thanet będąc już znanym malarzem. Oprócz Turner Contemporary, w gminie Thanet znajdują się także inne obiekty kultury, nawiązujące do przeszłości tego obszaru. Najważniejsze z nich to: Dickens House Museum w Broadstairs, The Shell Grotto, Muzeum Powell-Cotton w Birchington, lotnisko RAF Manston, z samolotami typy Spitfire i Hurricane oraz domy w stylu Art-Deco.

Reasumując w krajobrazie Thanet odcisnęły swe piętno: funkcja militarno-obronna, gospodarka morska, rolnictwo, turystyka, a współcześnie coraz ważniejsze znaczenie odgrywa także funkcja kulturalna. Każda z tych funkcji wpłynęła na rozwój społecznogospodarczy regionu stanowiąc o jego współczesnym charakterze.

Miasto Hel położone jest w woj. pomorskim w północnej części Polski na wybrzeżu Morza Bałtyckiego na półwyspie noszącym tę samą nazwę. Rozwój społeczno-ekonomiczny oraz główne funkcje społeczno-gospodarcze, podobnie jak w przypadku Thanet, wynikają z położenia nadmorskiego. Początkowo osada położona była około 1500 metrów na zachód od obecnej, jednakże na skutek działalności eolicznej fal morskich nastąpiła nadbudowa mierzei, a na jej cyplu powstał ośrodek Hel w obecnej lokalizacji. Od XII do XV wieku miasto, które wówczas nazywało się Gallen, było ważnym ośrodkiem handlu śledziami, a funkcji gospodarczej związanej z połowem ryb towarzyszyły działania na rzecz żeglarzy, dla których Gallen odgrywał ważne znaczenie jako punkt orientacyjny. W XV wieku Gallen został podporządkowany Gdańskowi, co spowodowało spadek znaczenia tego ośrodka. Ponowny rozkwit miasta Hel odnotowano w drugiej połowie XIX wieku i w pierwszych dekadach XX wieku. W 1893 roku zbudowano w Helu port morski, a wraz z rozwojem turystyki na przełomie wieków miejscowość stopniowo zaczynała pełnić funkcję ośrodka wypoczynkowego. W latach 70. XIX wieku Hel uzyskał połączenie kolejowe i został włączony w system kolejowych dróg lokalnych rozbudowywanych w państwie pruskim. Po zakończeniu I wojny światowej Hel został włączony do Polski i stał się ważnym ośrodkiem wypoczynkowym dla mieszkańców Polski oraz przybywających coraz liczniej gości zza granicy. Funkcja turystyczna stała się ważną funkcją społeczno-gospodarczą miasta. W okresie międzywojennym Hel zaczął odgrywać także bardzo istotną rolę z punktu widzenia obrony militarnej wybrzeża. W 1936 powstał Rejon Umocniony Hel i stopniowo w miejscowości zaczęła dominować funkcja militarna, wskutek czego wprowadzane były ograniczenia w ruchu osób. W ten sposób Hel powoli tracił na znaczeniu jako środek turystyczny. Miejscowość odegrała szczególną rolę w czasie obrony wybrzeża podczas II wojny światowej. Również po 1945 roku, po zakończeniu działań wojennych, utrzymano w Helu dominację funkcji strategiczno- 
-militarnej. W drugiej połowie XX wieku atrakcyjność wypoczynkowa wybrzeża helskiego była przyczyną stopniowego przywracania znaczenia funkcji turystycznej. Jednakże, w związku ze szczególnym znaczeniem funkcji militarnej, przyjazdy turystów do Helu były ściśle reglamentowane. Pomimo tych ograniczeń w okresie komunistycznym odnotowano ciągły wzrost ruchu turystycznego w Helu. Formalnie ograniczenia w ruchu osób do Helu zniesiono dopiero w 1989 roku. Przy czym aż do 2002 roku utrzymywała się funkcja militarna jako dominująca funkcja Helu. W ostatnich dwóch dekadach nawiązano do dawnych tradycji wypoczynkowych, a turystyka stała się dominującą funkcją społeczno-gospodarczą $\mathrm{w}$ Helu. Ponadto ważne znaczenie na Helu ma działalność Fokarium Stacji Morskiej Instytutu Oceanografii Uniwersytetu Gdańskiego, ośrodka naukowego, którego celem jest odtworzenie kolonii foki szarej w południowej części Morza Bałtyckiego. Fokarium jest dużą atrakcją Helu, w ciągu roku odwiedza ten obiekt kilkaset tysięcy turystów. Oprócz Fokarium w Helu znajdują się inne atrakcje turystyczne o charakterze edukacyjnym i kulturowym, w tym przede wszystkim wymienić należy: Muzeum Obrony Wybrzeża, Muzeum Rybołówstwa, Latarnia Morska, Muzeum Morświna i inne.

Reasumując w krajobrazie Helu można odnaleźć ślady działalności związanej z: funkcją militarnoobronną, gospodarką morską, w tym przede wszystkim z handlem śledziami, turystyką oraz od kilkudziesięciu lat intensywnie rozwijającą się funkcją naukową i ekologiczną. Każda $\mathrm{z}$ tych funkcji wpłynęła na rozwój społeczno-gospodarczy regionu stanowiąc o jego współczesnym charakterze.

To co łączy obydwie jednostki samorządu terytorialnego - to współcześnie dominacja turystyki w strukturze gospodarki oraz pełnienie funkcji militarno-obronnej w czasie II wojny światowej. Ponadto w przeszłości w obu jednostkach zaznaczył się wpływ gospodarki związanej z morzem oraz pełnienie istotnej roli dla żeglarstwa w związku ze szczególnym znaczeniem punktów orientacyjnych dla żeglarzy. Jednocześnie odnotować należy, że współcześnie następuje pewnego rodzaju uzupełnienie dotychczas ukształtowanych funkcji działalnością o charakterze kulturalnym, przy czym w Helu dominuje nurt naukowo-ekologiczny, zaś w Thanet - wystawienniczy.

Zasięg przestrzenny a dlugość pobytu turystów w kontekście dominującej grupy wypoczynku. Jako kategorie zróżnicowania zasięgu przestrzennego miejsca zamieszkania turystów wyróżniono: region, kraj, zagranica. Jako region dla Helu przyjęto województwo pomorskie w Polsce, zaś dla Thanet hrabstwo Kent w Wielkiej Brytanii. Jeśli chodzi o czas pobytu przyjęto, zgodnie $\mathrm{z}$ ujęciem $\mathrm{w}$ literaturze przedmiotu (Tourism 2020), trzy przekroje czasowe: turystyka jednodniowa, krótko-okresowa, obejmująca podróże z 1 do 3 noclegów (2-4 dni), turystyka długo okresowa (5 i więcej dni). Jednakże w kategorii turystyka długookresowa dodatkowo przeprowadzono analizę w podziale na dwa przekroje czasowe: (a) 5-7 dni i (b) 8 dni i więcej. Zależność między długością wypoczynku a zasięgiem przestrzennym analizowano w kontekście grupy wypoczynku, w której realizowano pobyt $\mathrm{w}$ regionach.

Hel. Wśród turystów, z którymi przeprowadzono badania ankietowe $\mathrm{w}$ miejscowości Hel, można wyróżnić dominujące dwie grupy. Byli to turyści jednodniowi, którzy stanowili 48,9 \% respondentów oraz turyści długookresowi - 46,1\% turystów. Najmniej liczną grupą turystów byli turyści krótkookresowi $-5,0 \%$ turystów. Wśród turystów jednodniowych dominowały osoby pochodzące $\mathrm{z}$ kraju $(91,2 \%)$, przy małym udziale turystów $\mathrm{z}$ regionu $(8,8 \%)$. Wśród turystów jednodniowych pochodzących z kraju zdecydowanie najwięcej jest osób, które przebywały na dłuższym wypoczynku w innych miejscowościach nadmorskich, a do Helu przyjechali na krótką jednodniową, czasami kilkugodzinną, wycieczkę.

Wśród turystów długookresowych dominowały osoby pochodzące z kraju 94,8 \% przy nieznacznym udziale turystów z regionu 3,1 \% i z zagranicy 2,1\%. Warto zwrócić uwagę, że wśród turystów długookresowych przeważały osoby przebywające w Helu 8 dni i więcej niż ci, którzy spędzili 5-7 dni. Spośród turystów krótkookresowych, stanowiących w Helu nieliczną grupę, przeważały osoby pochodzące z kraju przy współudziale Polaków z paszportem obcego kraju oraz kilku osób pochodzących z zagranicy, przy nieznacznym udziale turystów $\mathrm{z}$ regionu.

Reasumując w miejscowości Hel najliczniejszą grupę stanowili turyści jednodniowi pochodzący głównie z kraju. Na te grupę składają się najczęściej rodziny wypoczywające $\mathrm{w}$ sąsiadujących miejscowościach oraz zorganizowane grupy, przede wszystkim młodzieżowe. Rodziny z dziećmi najczęściej ograniczają swój pobyt w Helu do spaceru po mieście oraz pobycie na plaży, natomiast dla większości grup młodzieżowych najważniejszym punktem programu w Helu było Fokarium. Wśród turystów długookresowych dominowały rodziny z dziećmi oraz osoby wypoczywające indywidualnie. Dla turystów krótkookresowych oprócz wypoczynku ważne znaczenie miały obiekty kultury oraz uczestnictwo w organizowanych w Helu imprezach o charakterze kulturowym.

Można więc uznać, że Hel pełni rolę krajowego długookresowego ośrodka wypoczynkowego, a jednocześnie jest atrakcją turystyczną dla osób wypoczywających w sąsiadujących miejscowościach turystycznych.

Thanet. Wśród turystów, z którymi przeprowadzono badanie $\mathrm{w}$ gminie Thanet dominowali turyści długookresowi, którzy stanowili 51,7 \% turystów. Przy czym znaczny udział wśród tej grupy stanowiły 
Zasięg przestrzenny a czas pobytu turystów w miejscowości Hel

Tabela 2

\begin{tabular}{|c|c|c|c|c|c|c|c|c|}
\hline \multirow{3}{*}{$\begin{array}{c}\text { Czas } \\
\text { pobytu }\end{array}$} & \multicolumn{8}{|c|}{ Zasięg przestrzenny } \\
\hline & \multicolumn{2}{|c|}{ region } & \multicolumn{2}{|c|}{ kraj } & \multicolumn{2}{|c|}{$\begin{array}{c}\text { Kraj + polscy } \\
\text { emigranci }\end{array}$} & \multicolumn{2}{|c|}{ Zagranica } \\
\hline & $\begin{array}{c}\text { liczba } \\
\text { wywiadów }\end{array}$ & $\begin{array}{l}\text { Liczba } \\
\text { turystów }\end{array}$ & $\begin{array}{c}\text { liczba } \\
\text { wywiadów }\end{array}$ & $\begin{array}{c}\text { Liczba } \\
\text { turystów }\end{array}$ & \begin{tabular}{c|} 
liczba \\
wywiadów
\end{tabular} & $\begin{array}{c}\text { Liczba } \\
\text { turystów }\end{array}$ & $\begin{array}{c}\text { liczba } \\
\text { wywiadów }\end{array}$ & $\begin{array}{l}\text { Liczba } \\
\text { turystów }\end{array}$ \\
\hline 1 dzień & 4 & 18 & 21 & 187 & & & & \\
\hline $2-4 \mathrm{dni}$ & 1 & 2 & 2 & 7 & 1 & 8 & 1 & 4 \\
\hline 5-7 dni & & & 15 & 88 & & & & \\
\hline 8 i powyżej & 2 & 6 & 14 & 95 & & & 1 & 4 \\
\hline razem & 7 & 26 & 52 & 377 & & & 3 & 16 \\
\hline & & & $\operatorname{Razc}$ & wywiadó & 62. Razem & rystów 419 & & \\
\hline
\end{tabular}

Źródło: opracowanie własne

osoby przebywające w Thanet 8 dni i dłużej. Przeważały osoby z zagranicy $(56,5 \%)$ przy pewnym udziale turystów z kraju (30,6 \%) oraz z regionu, do którego włączono także Londyn (12,9 \%). Można uznać, że zróżnicowanie struktury przestrzennej turystów długookresowych w Thanet było duże, przy zaznaczającej się jednakże pewnej dominacji turystów zagranicznych, wśród których znaczną grupę stanowili uczestnicy kursów językowych.

Wśród turystów jednodniowych, którzy stanowili w Thanet $37,9 \%$ zbadanej populacji, dominowały osoby pochodzące $\mathrm{z}$ regionu i sąsiadującego Londynu, przy pewnym udziale zamieszkujących w kraju. W znacznej części były to zorganizowane grupy, przybyłe do Thanet celem odwiedzenia obiektów kultury, w tym przede wszystkim Galerii Turner Contemporary oraz obserwacji imprezy folklorystyczno-plenerowej. Turyści krótkookresowi, którzy stanowili 10,4\% zbadanej populacji, podobnie jak 1-dniowi przybyli z regionu oraz z kraju. Wśród nich znaczną grupę stanowiły rodziny z dziećmi, a głównym celem był wypoczynek na plaży oraz uczestnictwo w imprezach kulturalnych.

Reasumując w gminie Thanet można wyróżnić dwie dominujące grupy turystów. Stosunkowo liczną grupę stanowili turyści długookresowi, o zróżnicowanym zasięgu przestrzennym, przy dominacji osób pochodzących z zagranicy. Drugą pod względem liczebności grupą turystów byli turyści jednodniowi, wśród których przeważali mieszkańcy regionu, do którego włączono Londyn. Natomiast najmniej liczną grupę stanowili turyści krótkookresowi, wśród których byli głównie mieszkańcy kraju. Można uznać, że Thanet jest ważnym krajowym ośrodkiem turystycznym, przy zaznaczającym się coraz większym znaczeniu turystyki międzynarodowej.

Reasumując w obu jednostkach samorządu terytorialnego bardzo istotne znaczenie miała turystyka długookresowa, przy czym zaznaczyły się różnice w zakresie profilu grupy wypoczynku w tych miejscowościach. W Helu dominowały rodziny i osoby prywatne zamieszkujące głównie w kraju, natomiast w Thanet - bardzo duży udział miały zagraniczne grupy zorganizowane przebywające na kursach językowych przy pewnym udziale osób indywidualnych i wypoczywających $\mathrm{z}$ rodziną zamieszkujących w kraju. Warto zauważyć, że w obu badanych obszarach duży udział stanowiły pobyty 8 dniowe i dłuższe. Istotne znaczenie $\mathrm{w}$ obu miejscowościach miała także turystyka jednodniowa. Zarówno w Helu jak i w Thanet, przyczyną tych krótkich wizyt turystycznych były lokalne atrakcje turystyczne - odpowiednio Fokarium i Turner Contemporary oraz chęć odwiedzenia tego miasta - obszaru. Jednocześnie w obu miejscowościach małe znaczenie miała turystyka krótkookresowa, co jest to związane z charakterem

Zasięg przestrzenny a czas pobytu turystów w miejscowości Thanet

Tabela 3

\begin{tabular}{|l|c|c|c|c|c|c|c|c|}
\hline \multirow{3}{*}{$\begin{array}{c}\text { Czas } \\
\text { pobytu }\end{array}$} & \multicolumn{9}{|c|}{ region } & \multicolumn{2}{c|}{ London } & \multicolumn{2}{c|}{ Kraj } & \multicolumn{2}{c|}{ Zagranica/region } \\
\cline { 2 - 9 } & $\begin{array}{c}\text { liczba } \\
\text { wywiadów }\end{array}$ & $\begin{array}{c}\text { Liczba } \\
\text { turystów }\end{array}$ & $\begin{array}{c}\text { liczba } \\
\text { wywiadów }\end{array}$ & $\begin{array}{c}\text { Liczba } \\
\text { turystów }\end{array}$ & $\begin{array}{c}\text { liczba } \\
\text { wywiadów }\end{array}$ & $\begin{array}{c}\text { Liczba } \\
\text { turystów }\end{array}$ & $\begin{array}{c}\text { liczba } \\
\text { wywiadów }\end{array}$ & $\begin{array}{c}\text { Liczba } \\
\text { turystów }\end{array}$ \\
\hline 1 dzień & 6 & 15 & 4 & 65 & 3 & 11 & & \\
\hline 2-4 dni & 2 & 4 & 1 & 3 & 5 & 18 & & \\
\hline $5-7$ dni & 1 & 6 & 2 & 6 & 4 & 26 & 1 & 9 \\
\hline 8 i powyżej & 1 & 4 & & & 3 & 12 & 4 & 61 \\
\hline razem & 10 & 29 & & & 15 & 67 & 5 & 70 \\
\hline
\end{tabular}


tych obszarów. Analizowane jednostki samorządu terytorialnego są zdominowane przez walory wypoczynkowe, co sprzyja odbudowywaniu dobrostanu fizycznego, a co z kolei można osiągnąć w dłuższej perspektywie czasowej.

Struktura czasu wypoczynku jako wskaźnik dominujących typów turystyki. Dla wyróżnionych w pierwszym etapie badań grup turystów w poszczególnych miejscowościach przeprowadzono analizę struktury spędzania czasu. Na tej podstawie określono znaczenie dóbr kultury jako czynnika pobudzającego ruch turystyczny. Przy opisie wyników wykorzystano odpowiedzi na pytania jakościowe dotyczące odwiedzanych obiektów kulturowych.

Hel - turyści długookresowi. Wśród turystów długookresowych przebywających w Helu dominowały osoby pochodzące z kraju (94,8\%), przy nieznacznym udziale turystów z regionu $(3,1 \%)$ i z zagranicy $(2,1 \%)$. Dobra kultury były szczególnie ważne dla grup pozostających w mniejszości, czyli dla gości z zagranicy i mieszkańców regionu. Natomiast stanowiący większość wśród wypoczywających długookresowo turystów pochodzących z kraju, obiekty kultury były istotnym, ale nie najważniejszym elementem ich aktywności w czasie pobytu. Więcej czasu spędzali na plaży oraz na spacerze (Tabela 4).

Dla 53 spośród 183 turystów długookresowych pochodzących z kraju wypoczywających na Helu w towarzystwie rodziny i przyjaciół oraz dla małżeństw dobra kultury odgrywały jednakże ważną rolę. Odwiedzali najczęściej system umocnień i Muzeum Obrony Wybrzeża, obiekty dziedzictwa kulturowo-przyrodniczego (Muzeum Morświna, Fokarium) oraz uczestniczyli w imprezie plenerowo-historycznej. Ta grupa turystów podkreślała atrakcyjność Helu oraz dobre warunki wypoczynku - wskazywali, że czują się tu ,jak u siebie w domu". Odnotowano w tej grupie również takich turystów, którzy przyjeżdżają do Helu corocznie, a dla niektórych - był to przyjazd polecony przez znajomych i członków rodzin. Dla kolejnej grupy turystów długookresowych z kraju (92 osoby na 183 turystów), z dominującym udziałem grup zorganizowanych i rodzin z dziećmi obiekty kultury odgrywały minimalną rolę. Grupy zorganizowane koncentrowały się na realizacji innych celów niż odwiedzanie obiektów kultury, w tym możliwość zabawy, a także praca dorywcza, i tylko sporadycznie odwiedzali obiekty kultury, głównie Fokarium. Kolejna grupa (38/183 osoby) turystów długookresowych nie odwiedziła żadnego obiektu kultury w Helu. Były to rodziny z małymi dziećmi oraz jedna grupa zorganizowana - członkowie chóru, którzy mieli próby przez 6 godzin dziennie, a pozostały czas spędzali na plaży.

Jeśli chodzi o nieliczną grupę turystów długookresowych z regionu (6 osób) to stosunek do dóbr kultury był bardzo zróżnicowany. Dla grupy przyjaciół, tworzącej grupę rekonstrukcyjną, udział w imprezie plenerowo-historycznej był zasadniczą przyczyną przyjazdu do Helu, dlatego spędzali w obiektach kultury do 8 godzin dziennie. Natomiast dla matki z dzieckiem ważne znaczenie miały kwestie rodzinne. Wśród nielicznej grupy turystów zagranicznych wypoczywających długookresowo na Helu odnotowano 4-osobową rodzinę $\mathrm{z}$ zagranicy (Praga - stolica Czech) przyjeżdżającą corocznie celem uczestnictwa $\mathrm{w}$ imprezie plenerowo-historycznej. Można powiedzieć, że dla tych turystów walory kulturowe miały zasadnicze znaczenie przy wyborze Helu jako destynacji.

Reasumując należy stwierdzić, że walory kulturowe dla turystów długookresowych wypoczywających w Helu miały zróżnicowane oddziaływanie. Dla turystów z kraju niezależnie od grupy wypoczynku zdecydowanie ważniejsze były walory wypoczynkowe, przy czym dobra kultury stanowily istotne uzupełnienie wypoczynku tej grupy turystów. Natomiast dla będących w zdecydowanej mniejszości wypoczywających pochodzących z zagranicy oraz $\mathrm{z}$ regionu, dobra kultury były zasadniczym celem przyjazdu do Helu. Te grupy turystów należy traktować jako ambasadorów rozwoju długookresowej turystyki kulturowej w Helu.

Hel turyści jednodniowi. Wśród turystów jednodniowych przebywających w Helu zdecydowanie dominowały osoby pochodzące z kraju, którzy najwięcej czasu przebywali na plaży i na spacerze. Niektórzy z nich (48 na 187 osób - głównie rodziny z dziećmi oraz grupy przyjaciół) odwiedzali obiekty kultury, co zajmowało im od 0,5 do 2 godzin dzien-

Tabela 4

Sposoby spędzania czasu przez turystów długookresowych w miejscowości Hel

\begin{tabular}{|c|c|c|c|c|c|c|c|}
\hline \multirow{3}{*}{$\begin{array}{c}\text { Region } \\
\text { pochodzenia }\end{array}$} & \multirow{2}{*}{\multicolumn{2}{|c|}{$\begin{array}{l}\text { Liczebność grupy } \\
\text { wypoczynku }\end{array}$}} & \multicolumn{5}{|c|}{ Sposoby spędzania wolnego czasu } \\
\hline & & & Na plaży & Spacer & rower & $\begin{array}{c}\text { Dobra } \\
\text { kultury }\end{array}$ & inne \\
\hline & Liczba osób & $\%$ & \multicolumn{5}{|c|}{ Średni czas dziennie przypadajacy na 1 turyste (h,min) } \\
\hline region & 6 & 3,1 & $0 \mathrm{~h} 50 \mathrm{~min}$ & $1 \mathrm{~h} 0 \mathrm{~min}$ & $0 \mathrm{~h} 00 \mathrm{~min}$ & $6 \mathrm{~h} 00 \mathrm{~min}$ & $2 \mathrm{~h} 00 \mathrm{~min}$ \\
\hline kraj & 183 & 94,8 & $2 \mathrm{~h} 16 \mathrm{~min}$ & $2 \mathrm{~h} 29 \mathrm{~min}$ & $0 \mathrm{~h} 14 \mathrm{~min}$ & $1 \mathrm{~h} 26 \mathrm{~min}$ & $1 \mathrm{~h} 42 \mathrm{~min}$ \\
\hline zagranica & 4 & 2,1 & $0 \mathrm{~h} 00 \mathrm{~min}$ & $3 \mathrm{~h} 00 \mathrm{~min}$ & $0 \mathrm{~h} 00 \mathrm{~min}$ & $8 \mathrm{~h} 30 \mathrm{~min}$ & $2 \mathrm{~h} 30 \mathrm{~min}$ \\
\hline Razem & 193 & 100 & & & & & \\
\hline
\end{tabular}

Źródto: opracowanie własne 
Sposoby spędzania czasu przez turystów jednodniowych w miejscowości Hel

\begin{tabular}{|l|c|c|c|c|c|c|c|}
\hline \multirow{2}{*}{$\begin{array}{l}\text { Region } \\
\text { pochodzenia }\end{array}$} & \multicolumn{2}{|c|}{$\begin{array}{c}\text { Liczebność grupy } \\
\text { wypoczynku }\end{array}$} & \multicolumn{5}{c|}{ Sposoby spędzania wolnego czasu } \\
\cline { 2 - 7 } & Liczba osób & \% & \multicolumn{3}{|c|}{ Średni czas dziennie przypadający na 1 turystę } \\
\hline region & 18 & 8,8 & $0 \mathrm{~h} 20 \mathrm{~min}$ & $1 \mathrm{~h} 14 \mathrm{~min}$ & $1 \mathrm{~h} 17 \mathrm{~min}$ & $3 \mathrm{~h} 43 \mathrm{~min}$ & 0 \\
\hline kraj & 187 & 91,2 & $2 \mathrm{~h} 39 \mathrm{~min}$ & $2 \mathrm{~h} 28 \mathrm{~min}$ & $0 \mathrm{~h} 6 \mathrm{~min}$ & $0 \mathrm{~h} 39 \mathrm{~min}$ & $0 \mathrm{~h} 3 \mathrm{~min}$ \\
\hline zagranica & 0 & 0 & & & & & \\
\hline Razem & 205 & 100 & & & & & \\
\hline
\end{tabular}

nie. Najczęściej byli zainteresowani umocnieniami militarnymi, Fokarium oraz Muzeum Morświna, a także założeniami architektonicznymi oraz tradycjami Helu jako miasta wypoczynkowego.

Jednakże dla największej liczby turystów jednodniowych pochodzących z kraju powodem zwiedzenia było miasto jako kurort. Dla 80 osób przybyłych w grupach zorganizowanych główną formą aktywności w Helu był spacer i pobyt na plaży. Była to młodzież wypoczywająca w sąsiednich miejscowościach, a do Helu przyjechali na 1-dniową wycieczkę. Większe zainteresowanie obiektami kultury wykazywali uczestnicy obozu sportowego, którzy przebywając $\mathrm{w}$ innym ośrodku przyjechali specjalnie po to, aby zobaczyć umocnienia militarne. Dla 10-osobowej grupy przyjaciół w młodym wieku (młodzież licealna) głównym celem 1-dniowego pobytu na Helu była plaża oraz centra rozrywki. Odwiedzające 1-dniowo Hel rodziny (16 osób) nie odwiedziły żadnych obiektów o charakterze kulturowym. Można stwierdzić, że dla przebywających w Helu 1 dzień turystów pochodzących z kraju głównym celem jest miasto jako kurort, spacer po plaży, natomiast poznanie obiektów i dóbr kultury jest dość rzadkie. Natomiast obiekty kulturowe były istotnym czynnikiem powodującym odwiedzenie Helu przez stosunkowo nielicznych (18 osób) turystów jednodniowych pochodzących z regionu. Niezależnie od grupy wypoczynku na odwiedzenie obiektów historycznych przeznaczano po kilka godzin w ciągu 1-dniowej wycieczki na Hel.

Reasumując Hel jawi się jako kurort będący atrakcją turystyczną dla wypoczywających w innych miejscowościach nadmorskich mieszkańcach kraju, przyjeżdżających do Helu na 1 dzień. Zaś dla będących w mniejszości 1-dniowych turystów z regionu walory kulturowe były ważnym czynnikiem odwiedzenia miasta.

Thanet - turyści długookresowi. Turyści długookresowi byli dominujacca grupa wypoczywająca w Thanet. Dominowały wśród badanych $\mathrm{z}$ tej grupy osoby przybyłe z zagranicy (56,5\%), a najmniejszy udział mieli turyści zamieszkujący $\mathrm{w}$ regionie, do którego zaliczono również Londyn (12,9\%).

Wśród turystów zagranicznych największą grupą byli członkowie kursów językowych, którzy w czasie pobytu $\mathrm{w}$ Thanet łączyli naukę języka $\mathrm{z}$ wypoczynkiem. Znalazło to odzwierciedlenie w strukturze spędzania czasu w zależności od dnia tygodnia. W weekend, kiedy nie było zajęć językowych, na odwiedzenie obiektów kultury uczestnicy kursów językowych przeznaczali średnio po 3 godziny dziennie, natomiast w ciągu tygodnia było to zdecydowanie mniej - od 0,5 do 1 godziny. Przy czym ważne znaczenie miały niezależnie od dnia tygodnia spacery oraz przebywanie na plaży. Dla długookresowych turystów zagranicznych spędzających urlop w Thanet $\mathrm{w}$ gronie osób bliskich (rodzina) dobra kultury stanowiły, na równi z walorami wypoczynkowymi, o atrakcyjności tego miejsca. Wśród tej grupy główną przyczyną przyjazdu do Thanet było uczestnictwo w imprezie folkorystyczno-plenerowej. $\mathrm{Z}$ ich wypowiedzi wynikało, że jest to co najmniej powtórny przyjazd do Thanet, a równie ważne co walory kulturowe były czyste plaże oraz bliskość miejsca zamieszkania (północna Francja). Można uznać, że dla zagranicznych turystów długookresowych w Thanet ważną rolę pełniły kwestie językowe połączone $\mathrm{z}$ wypoczynkiem i poznawaniem regionu (,Learning English and discover the land").

Turyści pochodzący z kraju stanowili około $30 \%$ wypoczywających długookresowo w Thanet. Były to

Tabela 6

Sposoby spędzania czasu przez turystów długookresowych w miejscowości Thanet

\begin{tabular}{|l|c|c|c|c|c|c|c|}
\hline \multirow{2}{*}{$\begin{array}{c}\text { Region } \\
\text { pochodzenia }\end{array}$} & \multicolumn{2}{|c|}{$\begin{array}{c}\text { Liczebność grupy } \\
\text { wypoczynku }\end{array}$} & \multicolumn{5}{c|}{ Sposoby spędzania wolnego czasu } \\
\cline { 2 - 8 } & Na plaży & Spacer & rower & $\begin{array}{c}\text { Dobra } \\
\text { kultury }\end{array}$ & \multirow{2}{*}{ inne } \\
\cline { 2 - 8 } & Liczba osób & \% & \multicolumn{4}{|c|}{ Średni czas dziennie przypadający na 1 turystę } \\
\hline region & 16 & 12,9 & $3 \mathrm{~h} 15 \mathrm{~min}$ & $1 \mathrm{~h} 8 \mathrm{~min}$ & $2 \mathrm{~h} 19 \mathrm{~min}$ & $1 \mathrm{~h} 30 \mathrm{~min}$ & $0 \mathrm{~h} 00 \mathrm{~min}$ \\
\hline kraj & 38 & 30,6 & $2 \mathrm{~h} 25 \mathrm{~min}$ & $1 \mathrm{~h} 22 \mathrm{~min}$ & $0 \mathrm{~h} 00 \mathrm{~min}$ & $3 \mathrm{~h} 48 \mathrm{~min}$ & $0 \mathrm{~h} 00 \mathrm{~min}$ \\
\hline zagranica & 70 & 56,5 & $1 \mathrm{~h} 20 \mathrm{~min}$ & $1 \mathrm{~h} 05 \mathrm{~min}$ & $0 \mathrm{~h} 00 \mathrm{~min}$ & $1 \mathrm{~h} 14 \mathrm{~min}$ & $0 \mathrm{~h} 00 \mathrm{~min}$ \\
\hline Razem & 124 & 100 & & & & & \\
\hline
\end{tabular}


głównie rodziny, małżeństwa oraz grupy przyjaciół. Dla większości z nich (28 spośród 38) dobra kultury odgrywały podstawową i zasadniczą rolę decydującą o przyjeździe do Thanet. W obiektach kultury i na imprezach (w tym folklorystyczno-plenerowej) spędzali od 3 do 6 godzin dziennie. Ta grupa turystów charakteryzowała się dobrą znajomością walorów kulturowych, odwiedziła lub planowała odwiedzić istniejące $\mathrm{w}$ gminie obiekty kultury. Dla tej grupy turystów ważne były także wycieczki w hrabstwie Kent (głównie Dover i Cantenbury). Należy zauważyć, że w tej grupie turystów ważne znaczenie miało również bytność w obiektach gastronomicznych (do 3-4 godz. dziennie), a także plażowanie oraz spacery. Odnotować więc należy dużą intensywność spędzania czasu przez krajowych turystów długookresowych w Thanet, jednakże w znacznej mierze wynika to $\mathrm{z}$ charakteru imprezy folklorystyczno-plenerowej.

Dla turystów długookresowych pochodzących $\mathrm{z}$ regionu $(12,9 \%$ populacji turystów długookresowych) obiekty kulturowe miały mniejsze znaczenie - w ciągu swojego pobytu przeznaczyli na kulturę średnio dziennie od 1 do 2 godzin, a plażowanie i spacery były dominującą formą wypoczynku (5-6 godzin dziennie). $Z$ wypowiedzi tych turystów wynikało, że przyjeżdżali do Thanet corocznie $\mathrm{i}$ znali istniejące $\mathrm{w}$ gminie obiekty kultury. W tej grupie ważne znaczenie miały również pobyty w restauracjach (po 5 godz. dziennie). W mniejszości byli wypoczywający długookresowo $\mathrm{w}$ Thanet, a pochodzący $\mathrm{z}$ Londynu, dla których odwiedzanie obiektów kultury stanowiło istotną część dnia (około 2,5 godzin dziennie) przy czym równie ważne były restauracje i bary oraz bycie na plaży i spacery.

Reasumując turystyka długookresowa w Thanet została zdominowana przez uczestników kursów językowych, których cechą jest łączenie nauki języka z wypoczynkiem i odwiedzaniem obiektów kultury. Istotną grupę stanowią również turyści międzynarodowi oraz krajowi, przyjeżdżający do Thanet $\mathrm{z}$ rodziną lub grupą przyjaciół, którzy przy dużej atrakcyjności wypoczynkowej umiejętne wplatają korzystanie z dóbr kultury.

Thanet - turyści jednodniowi. Wśród turystów jednodniowych, którzy stanowili około $1 / 3$ poddanych badaniu turystów w Thanet, dominowały osoby pochodzące $\mathrm{z}$ regionu i sąsiadującego Londynu łącznie było to 87,8 \% spośród wszystkich turystów jednodniowych. Dla zdecydowanej większości z tej grupy turystów podstawowe znaczenie miało odwiedzenie muzeów i galerii, w tym: Thurner Contemporary i Dickens Muzeum, oraz obserwacje i udział w imprezie folklorystyczno-plenerowej. Tylko 5 osób wskazało plażę i morze jako główną przyczynę przyjazdu (Tabela 7).

Nieliczna grupa turystów jednodniowych pochodzących z kraju (12,1 \%) wykazywała duże zainteresowanie obiekty kultury, w których średnio członkowie tej grupy spędzali najwięcej czasu, bo prawie 2 godziny. Równie ważna była dla nich plaża (1,5 godz.), natomiast pozostałe formy aktywności, w tym spacer i rower, nie zajmowały wiele czasu. Spośród obiektów kultury, które odwiedzili wskazywali przede wszystkim muzea, w tym Spitfire Memorial Musem oraz atrakcyjność miejscowości wypoczynkowych.

Reasumując turyści jednodniowi w Thanet koncentrowali się w znacznej mierze na obiektach kultury, dla zdecydowanej większości z nich odwiedzenie Muzeów oraz galerii Turner Contemporary było istotnym celem przyjazdu. Natomiast pozostałe formy wypoczynku miały uzupełniające znaczenie. Należy zaznaczyć również, że turystyka jednodniowa w Thanet zdominowana była przez mieszkańców Londynu, przy minimalnym uzupełnieniu turystami z regionu i kraju.

Wnioski. Istotnym stymulatorem rozwoju turystyki, jako funkcji społeczno-gospodarczej, są znajdujące się i odpowiednio zagospodarowane walory turystyczne, co w szczególności odnotować można w jednostkach samorządu terytorialnego na poziomie lokalnym. Zlokalizowane walory turystyczne dają podstawę do intensyfikacji ruchu turystycznego, a tym samym przyczyniają się do rozwoju społeczno-gospodarczego. W artykule w szczególności podjęto analizę tych przypadków, w których można mówić o dominacji walorów przyrodniczych, jednakże istnienie walorów antropogenicznych, przy odpowiednich działaniach władz samorządowych, jest elementem podnoszącym atrakcyjność turystyczną regionu turystycznego. Zgodnie z założeniami do badania wybrano jednostki samorządu terytorialnego na poziomie lokalnym, w których w strukturze walorów turystycznych wyraźnie dominują walory wypoczynkowe nad antropogenicznymi, natomiast te drugie

Tabela 7

Sposoby spędzania czasu przez turystów jednodniowych w miejscowości Thanet

\begin{tabular}{|c|c|c|c|c|c|c|c|}
\hline \multirow{3}{*}{$\begin{array}{c}\text { Region } \\
\text { pochodzenia }\end{array}$} & \multirow{2}{*}{\multicolumn{2}{|c|}{$\begin{array}{c}\text { Liczebność grupy } \\
\text { wypoczynku }\end{array}$}} & \multicolumn{5}{|c|}{ Sposoby spędzania wolnego czasu } \\
\hline & & & Na plaży & Spacer & rower & Dobra kultury & inne \\
\hline & Liczba osób & $\%$ & \multicolumn{5}{|c|}{ Średni czas dziennie przypadający na 1 turystę } \\
\hline region & 80 & 87,9 & $1 \mathrm{~h} 35 \mathrm{~min}$ & $2 \mathrm{~h} 23 \mathrm{~min}$ & $0 \mathrm{~h} 00 \mathrm{~min}$ & $2 \mathrm{~h} 29 \mathrm{~min}$ & $0 \mathrm{~h} 00 \mathrm{~min}$ \\
\hline kraj & 11 & 12,1 & $1 \mathrm{~h} 33 \mathrm{~min}$ & $0 \mathrm{~h} 22 \mathrm{~min}$ & $0 \mathrm{~h} 00 \mathrm{~min}$ & $1 \mathrm{~h} 44 \mathrm{~min}$ & $0 \mathrm{~h} 22 \mathrm{~min}$ \\
\hline zagranica & 0 & 0 & & & & & \\
\hline Razem & 91 & 100 & & & & & \\
\hline
\end{tabular}


są również interesujące i mogą być istotnym elementem przyciągającym turystów.

W artykule wykazano zasadnicze różnice jeśli chodzi o zasięg przestrzenny turystów w badanych jednostkach samorządu terytorialnego. W grupie turystów długookresowych $\mathrm{w}$ gminie Thanet można mówić o zróżnicowanym zasięgu przestrzennym, przy dominacji osób pochodzących z zagranicy, natomiast w Helu wśród turystów długookresowych wyraźnie dominowali mieszkańcy kraju. Podobne różnice odnotowano wśród turystów jednodniowych, którymi w Thanet byli mieszkańcy regionu, do którego włączono Londyn, natomiast w Helu byli to mieszkańcy kraju, przebywający na dłuższym wypoczynku w sąsiadujących kurortach.

W artykule wykazano pewną zależność między okresem wypoczynku a istotnością walorów turystycznych, dla wypoczywających w perspektywie długookresowej, zarówno w Helu jak i w Thanet, dominujące znaczenie miały walory przyrodnicze $\mathrm{i}$ wypoczynkowe, jednakże odnotować należy także zainteresowanie obiektami kultury wśród tej grupy turystów. Tradycje turystyczne oraz atrakcje przyrodniczo-kulturowe stanowily główną przyczynę przyjazdów tej grupy turystów. Natomiast dla turystów przebywających 1 dzień widać zróżnicowanie między Polską a Wielką Brytanią. Na wyspach brytyjskich dla tej grupy turystów obiekty kultury miały podstawowe znaczenie, były stymulatorem przyjazdów, natomiast w Polsce była to chęć poznania kurortu jako miejsca, a nie jej zasobów kulturowych.

Można więc powiedzieć, że postawiona na wstępie teza, mówiąca że $\mathbf{w}$ regionach turystycznych $\mathbf{o}$ dominującej roli przyrodniczych oraz wypoczynkowych walorów turystycznych dobra kultury nie pełnią kluczowej roli, jednak przyczyniają się do zwiększenia ruchu turystycznego okazała się zasadna. W tym kontekście proces aktywizacji społeczności lokalnej oraz działania władz lokalnych na rzecz rozwoju produktów turystycznych w jednostkach stopnia podstawowego mają głęboki sens i uzasadnienie.

\section{References:}

1.Bedate A., Herrero L.C., Sanz J.A., 2004, Economic valuation of the cultural heritage: application to four case studies in Spain, Journal of Cultural Heritage, Vol. 5, Is. 1, Pages 101-111.

2. Bertacchini E., Nogare C.D., 2021, The economics of cultural tourism: New topics and methods, https://doi.org/10.1177/1354816621993662

3. Bille T., Schulze G., 2011, Culture in Urban and Regional Development, [w:] Handbook of the Economics of Art and Culture, V. A. Ginsburgh, D. Throsby (red.). Elsevier, North Holland, Amsterdam. Borys T., 2009.

4. Cernea M., 2001, Cultural Heritage and Development. A Framework for Action in the Middle East and North Africa. World Bank, Washington.

5. Eversole R., 2006, Heritage and Regional Development: a Process-and-Outcomes Typology. „Australasian Journal of Regional Studies", nr 3.

6. Hall C.M., Page S.J., 2014, The Geography of Tourism and Recreation Environment, Place and Space, 4th Edition, Published by Routledge.

7.Herrero-Prieto L.C., Gómez-Vega M., 2017, Cultural resources as a factor in cultural tourism attraction: Technical efficiency estimation of regional destinations in Spain, in: Tourism Economics, vol. 23, 2: pp. 260-280.

8. Korkuna O., Korkuna I., Kulyk O., 2020, Green Tourism as a Factor of Development of United Territorial Communities in Ukraine, in: Economic and Regional Studies, Vol. 13, No. 1, 126-136.

9. Koteski C., Jakovlev Z., Bardarova S., 2013, Natural and anthropogenic tourist value of the city Ohrid, Conference Paper, Konstantin Preslavski University of Shumen Department of Geography and Methodology of Theaching Geography.

10.Mason P., 2017, Geography of Tourism. Image, Impacts and Issues, Goodfellow Publishers, 256 pages.

11. McKercher, P., Ho, P.S.Y, Cros du H. (2005). Relationship between tourism and cultural heritage management: evidence from Hong Kong. Tourism Management. 26(4), 539-548.

12.Mensah I., 2016, Effects of Socio-Demographic Characteristics and Perceived Benefits of Tourism on Community Participation in Tourism in the Mesomagor Area of the Kakum National Park, Ghana. In: Athens Journal of Tourism Volume 3, Issue 3, Pages 211-230.

13.Girard L.F., Nijkamp P., 2016, Cultural Tourism and Sustainable Local Development, Routledge, 344 pages.

14.Rukuižienè R., 2014, Sustainable Tourism Development Implications to Local Economy, in: Regional Formation and Development Studies, No. 3(14), 170-177.

15. Suhel S., Bashir A., 2018, The role of tourism toward economic growth in the local economy, in: Economic Journal of Emerging Markets, 10(1), 32-39.

16.Tourism in 2019 [in polish: Turystyka w 2019], 2020, Statystycal analyses, GUS, Warsaw, Rzeszów.

17. Towse R., 2010, A Textbook of Cultural Economics, Cambridge University Press.

18.Zieba M., 2017, Cultural participation of tourist - Evidence from travel habits of Austrian residents, in: Tourism Economics, vol. 23, 2: pp. 295-315. 